\title{
From Information Management to Information Visualization
}

\section{Development of Radiology Dashboards}

Mahtab Karami ${ }^{1}$; Reza Safdari²

${ }^{1}$ Health Information Management Research Center (HIMRC), department of health information technology and management, school of Allied-Medical sciences, Kashan University of Medical Sciences, Kashan, Iran; ${ }^{2}$ Department of health information management, school of Allied-Medical sciences, Tehran University of Medical Sciences, Tehran, Iran

\section{Keywords}

Medical imaging, radiology, information, management, dashboard, visualization, performance indicators

\section{Summary}

Objective: The development and implementation of a dashboard of medical imaging department (MID) performance indicators.

Method: Several articles discussing performance measures of imaging departments were searched for this study. All the related measures were extracted. Then, a panel of imaging experts were asked to rate these measures with an open ended question to seek further potential indicators. A second round was performed to confirm the performance rating. The indicators and their ratings were then reviewed by an executive panel. Based on the final panel's rating, a list of indicators to be used was developed. A team of information technology consultants were asked to determine a set of user interface requirements for the building of the dashboard. In the first round, based on the panel's rating, a list of main features or requirements to be used was determined. Next, Qlikview was utilized to implement the dashboard to visualize a set of selected KPI metrics. Finally, an evaluation of the dashboard was performed.

Results: 92 MID indicators were identified. On top of this, 53 main user interface requirements to build of the prototype of dashboard were determined. Then, the project team successfully implemented a prototype of radiology management dashboards into study site. The visual display that was designed was rated highly by users.

Conclusion: To develop a dashboard, management of information is essential. It is recommended that a quality map be designed for the MID. It can be used to specify the sequence of activities, their related indicators and required data for calculating these indicators. To achieve both an effective dashboard and a comprehensive view of operations, it is necessary to design a data warehouse for gathering data from a variety of systems. Utilizing interoperability standards for exchanging data among different systems can be also effective in this regard.

\section{Correspondence to:}

Reza Safdari, Ph.D.

Department of health information management School of Allied-Medical sciences

Tehran University of Medical Sciences

Tehran

Iran

Email: rsafdari@tums.ac.ir

\section{Appl Clin Inform 2016; 7: 308-329}

http://dx.doi.org/10.4338/ACl-2015-08-RA-0104

received: October 21, 2015

accepted: January 26, 2016

published: May 11, 2016

Citation: Karami M, Reza Safdari R. From information management to information visualization: Development of radiology dashboards Appl Clin Inform 2016; 7: 308-229

http://dx.doi.org/10.4338/ACl-2015-08-RA-0104 


\section{Introduction}

Healthcare facilities are facing challenges of increasing cost and growing demand for higher efficiency and quality, as digital workflows are unavoidable. It seems that the solutions to overcome the challenges can be provided by utilizing technologies of workflow management. Workflow management is a modern technology which is centered on processes [1].

In healthcare, medical imaging department (MID) is a complex ecosystem in terms of diversity of services, clients, personnel, equipment, technologies, data and, information which are generated. Also, the workload of these departments is huge because most of the patients are the subject of at least one imaging test and diversity and costs of medical imaging techniques require a set of expensive devices and staff properly trained. Since the ultimate goal in hospital management is to improve quality of care along with reducing cost, MID is important from both financial and clinical aspects. Therefore, how to manage this department may have critical impact on the effectiveness and efficiency of the organization [2].

With the modernization of MIDs and with regard to using electronic information systems such as picture archiving and communication system (PACS), radiology information system (RIS), speech recognition systems, hospital information systems, electronic health records, and the workflow and informatics infrastructure supporting them became very complex. This is because it requires combining many computerized systems with different user environments to provide qualitative efficient services in less time [3].

In these departments, to optimize the workflow, the personnel and the radiologists should have access to real time information to act based on informed decisions. Dashboard technology can help them make informed decisions about workflow by creating a link between different information systems [3]. In his 2006 book, Information Dashboard Design, Stephen Few defined dashboard as "a visual display of the most important information needed to achieve one or more objectives; consolidated and arranged on a single screen so the information can be monitored at a glance."[4]. Data in the dashboard provides the possibility for the managers to monitor productivity in time every day[5]. In MID, a dynamic dashboard can be a useful tool for displaying accurate, in time, and critical information for the personnel and radiologists without sparing much effort or reducing productivity [6].

Thus, the ability to manage information, in addition to visualization of information, would allow MIDs to anticipate forthcoming variations and plan appropriately. Accordingly, this study proposed functionality steps that need to be taken to develop the dashboard for MIDs that can finally provide visibility of helpful and vital information for this complex and impressive department in order to create a strategic value.

\section{Methods}

In this qualitative and developmental research, a multi-method approach including interview, structured observation, questionnaire, and workplace walkthroughs have been employed as divided in four phases:

The first phase is related to the development of key performance indicator (KPI) metrics for MID. The main step for developing dashboard is determining indicators to display it [7]. According to the Joint Commission on the Accreditation of Healthcare Organizations (JCAHO), a KPI is "a measurement tool used to monitor and evaluate the quality of important governance, management, clinical, and support functions" [8].

During the investigation we found that there were no key indicator sets to evaluate the performance for academic MIDs in Iran. So, at first, the KPI metrics for these departments were developed using Delphi technique. The Delphi technique is a widely used and accepted method for gathering data from respondents within their domain of expertise. The technique is designed as a group communication process which aims to achieve a convergence of opinion on a specific real-world issue. The Delphi process has been used in various fields of study such as program planning which needs assessment, policy determination, and resource utilization to develop a full range of alternatives, exploring or exposing underlying assumptions, as well as correlating judgments on a topic spanning a 
wide range of disciplines. The Delphi technique is well suited as a method for consensus-building by using a series of questionnaires delivered using multiple iterations to collect data from a panel of selected subjects [9].

In this regard, several articles discussing performance metrics of MIDs were identified [8, 10-22]. All the metrics were extracted. In-depth semi-structured interviews were conducted with the clinical director of MID, the radiology business manager and a senior medical physicist to set up which metrics are relevant for each group. Next, a panel of imaging experts including 30 radiologists who were members of the Iranian Radiology Association and had more than 5 years of professional experience in directing MID were asked to rate these metrics with an open ended question included to seek further potential indicators. A second round was performed to confirm performance rating. In the questionnaire, scale of importance ranging was from 0 to 10, with 0 labeled "No importance" and 10 labeled "very high importance". For evaluating, a mean score above 5 fell in the acceptable rang and below 5 was considered as unacceptable. Based on the final panel's rating, a list of indicators to be used was developed.

The second phase is related to determine a set of user interface requirements to build the dashboard interface. Firstly, a review of literature [3, 7, 23-35] was performed. A number of features and their relevant elements were developed to assist and inform user interface requirements. Accordingly, an electronic checklist was designed and sent to a team of information technology consultants composed of health information management, medical informatics, and software engineering experts and radiologists as end users to determine a set of user interface requirements to inform the building of the dashboard. In the first round, based on the panel's rating, a list of main features or requirements to be used was determined.

The third phase is related to development of prototype dashboard at the study site. The KPI metrics and their ratings selected in the first phase were then reviewed by an executive panel composed of chief executive manager of hospital, directors of medical imaging, financial, health information management and quality improvement departments to select useful and feasible indicators for display in the dashboard. According to the limitations associated with the data necessary to calculate the metrics, This selection was done based on criteria such as impact of each metric on business function, availability and accessibility of the data for calculating them, and the ability to gather these data easily.

Next, Qlikview was utilized to implement dashboard to visualize the set of previously selected KPI metrics. For the data acquisition, the dashboard utilized a combined dataset from the RIS, financial information system (FIS), and personnel information system and PACS. Also, some of the data contained in paper documents was extracted and converted to Excel format before being subsequently imported, aggregated and visualized within Qlikview. Since in the MIDs, the dashboard data was the result of a number of information systems based on the internet and intranet, it was necessary to consider access levels for the users to have access to the dashboards. Therefore, the access levels were defined for key stakeholders.

Critical and main items were marked and altered by color coding to show levels of threats. These alerts were defined based on performance target thresholds which are derived from the yearly goals and objectives. Thresholds were also set for each metric in the executive panel and defined a target zone in green, a warning zone in yellow, and a trouble zone in red, as well as, updating information based on users' view, type of use, and importance of task was defined from daily to biweekly.

The fourth phase is related to evaluation of dashboard. There were three types of evaluations that are necessary. The first is to ensure that all user interface requirements are being met completely (based on the checklist enclose). The second is to ensure that all the KPI metrics are being displayed and calculated accurately. And the third is to measure the usability of the dashboard through the System Usability Scale (SUS). The System Usability Scale (SUS) provides a reliable tool for measuring the usability. It consists of a 10 item questionnaire with five response options for respondents; from strongly agree to strongly disagree. Originally, it was created by John Brooke in 1986. The focus of SUS is the ease of use of the dashboard being tested. This type of evaluation was performed by ten of the key stakeholders including executive hospital manager, director of department and eight of radiology staff who were involved in the management of the department.

To calculate the SUS score, the score contributions from each item was firstly summed up. Each item's score contribution will range from 0 to 4 . For items $1,3,5,7$, and 9 the score contribution is 
the scale position minus 1 . For items 2,4,6,8 and 10, the contribution is 5 minus the scale position. Multiply the sum of the scores by 2.5 to obtain the overall value of SU. The SUS scores have a range of 0 to 100 . Though the scores are $0-100$, these are not percentages and should be considered only in terms of their percentile ranking [36].

\section{Results}

92 MID important metrics in seven main groups were identified. These metrics have been presented in Tables $1-7$. Among them 10 metrics were selected for display in the dashboard ( Table 8). In the second phase, 53 main user interface requirements were determined for formation of the prototype of the dashboard ( Tables 9 to 15 ).

Radiology Management Dashboard ( $>$ Figure1) was an implemented prototype software tool for monitoring and managing medical imaging throughput performance. The dashboard had a number of tabs (including services, clients, personnel and cost-income), each containing a collective set of associated KPI metrics. All KPI data could be further filtered using various selection criteria such as modality, dates (day, week, month or year), exam and encounter type. User selection of these filters or combination of the filters results in the dashboard dynamically re-visualizing the data in realtime.

The main limitation of this study was lack of the data needed to calculate most of KPI metrics. Some of these required data were presented in $>$ Table 16 . To make a recommendation, a quality map must be designed for the MID. It can be used to specify the sequence of activities, their related indicators, and required data for calculating these indicators.

Finally, each of the various KPI metrics selected for display was individually tested for accuracy. Then, it was verified whether the KPI metrics were being calculated and visualized correctly. Also, as shown in $>$ Table 17 , the feedback among all evaluation interviewees revealed that the dashboards were easy to use and could support main user interface requirements. It is to mention that an impact of the dashboard on performance was not measured in this study.

\section{Discussion}

Quality in healthcare is related to both the content (medical outcomes) and the delivery (service, patient satisfaction with health care experience) $[15,16]$. So, to improve the quality required to ensure the proper planning done, a key element to planning is to select the required data and then adopt appropriate methods to collect data actively, consistently and effectively and represent them in performance indicator format [15].

Dashboard is an intellectual and visual tool for monitoring KPI which can capture key data from different systems and represents them summarized and useful in real-time with easier reading and interpretation for users [37]. This business intelligence tool can be applied in MIDs as used in other sections such as operation rooms [6], emergency rooms [38], diabetes [39], nursing management [40], and hospital infection control [41]. For example, Blaise et al. used the dashboard to control infections in their study [41]. MCLeod et al. suggested in a study that using dashboard will improve capacity and workflow management in emergency departments [42]. Wadsworth et al. believe that the dashboard provides the possibility of daily and real time monitoring of the productivity of organizations [5]. Zayfudim et al. implemented an electronic dashboard to increase compatibility with ventilator bundle measures and decrease rates of VPA in SICU [43].

Waitman et al. suggested that dashboard is an important platform to eliminate medication errors and optimize therapy [44]. Park et al. claimed that operation room dashboard is a powerful tool for objective decision making based on data to allocate resources, cost management, planning for expansion, and growth align with the stakeholders' incentives [38]. Stone-Griffith et al. evaluated the effect of using dashboard on the department's performance and suggested that "Between January 2007 and December 2010, overall length of stay decreased 10.5 percent while annual visit volume increased 13.6 percent. Thus, investing in the development and implementation of a system for ED 
data capture, storage, and analysis has supported operational management decisions, gains in ED efficiency, and ultimately improvements in patient care." [45].

In medical imaging, dashboard has some applications. For example, in a study, a web-based dashboard was constructed to automate the extraction, processing, and display of indicators and thereby provide useful and current data for management [46]. Repeats are indicators to improve service and quality. Through a digital $\mathrm{x}$-ray dashboard, dose management, $\mathrm{x}$-ray usage, and repeat analysis data can be made available. Therefore, this system can be an opportunity for more precise and frequent key parameter monitoring and intervention [3]. In another study, a PACS integrated digital dashboard designed to alert radiologists to their unsigned report queue status, coupled with an actionable link to the report signing application resulted in a reduction in the time between transcription and report finalization. The dashboard was well received by radiologists who reported high usage for signing reports [6]. Also, a PACS integrated digital dashboard can help address deficiencies and facilitate informed, optimized workflow decisions [47].

Selecting the type of indicators which should be included in dashboard is important. Depending on its situation, each department needs to measure the indicators related to its own area of performance, not all the indicators $[41,48]$, but indicators which are critical and special to the quality of their performance [49]. Each indicator is selected according to the business purpose and the ability to be gathered easily through standard business functions [50]. There are potentially hundreds of indicators that could be monitored in a radiology department. In addition, it is critical that the keys be meaningful, manageable, and measurable. Then, they should be grouped or categorized for manageability [17]. In this study a standard set of KPIs for academic radiology departments in using the Delphi technique was developed in 7 main groups which are mentioned in the result section.

Among safety KPI metrics, "patient identification error rate, site identification error rate, side identification error rate, and specimen labeling error rate" received high scores. Potential of harm in MIDs is high, particularly in interventional procedures, examinations involving radiation exposure, and drug administration. Because radiologic care affects most inpatients and outpatients at a medical center, the opportunities to provide safer care are great. So, it seems that all safety measures are needed in the radiology department because each type of error can lead to a sentinel event [20, 51, 52].

In the internal and external customers groups, "number of patient complaints", and in the service category, "examination volume, examination volume per modality and repeat rate" all received high scores. Since the radiology services are expensive, to avoid from repetition and obtain customer's satisfaction in order to increase the volume of services performed in the radiology department and then generate revenue for that is important [53-55]. In the value chain, creating and maintaining value for the customers by providing quality services is more cost-benefit than finding new customers. Also, keeping a customer will contribute to attracting new customers to radiology center. One of its advantages is reduction in the costs associated with advertising [56].

In the category of teaching and research, "ratio of number of patients to number of residents /fellowships", and in the category of excellence at workplace, "numbers of courses and training programs offered" all received high scores. As mentioned before various factors are involved in customer satisfaction such as delivering high quality services and avoiding from repeating. In MIDs, repetition rate is an important indicator because in many radiology practices in addition to the increased cost and loss of time for the patient, excessive exposure to radiation can lead to patient injury [18, $47,54]$. Reduction in quality of services and increased repetition rate could be due to inadequate training, increased workload, and lack of fit between staff and the number of patients in the radiology department [57-60]. Therefore, it is necessary for managers of the MIDs to enough pay attention to education, promotion, and workload of their staff. Also, there should be an appropriate correlation between number of patients and residents/fellowships in hospitals.

In the resource utilization group, "number of late-generation imaging devices and number of reports generated per radiologist" gained high scores. Since the worldwide tendency to use modern imaging services due to better accuracy has increased, imaging centers should be equipped with modern equipment to improve performance and increase the number of customers [22, 47].

Among financial performance KPI metrics "net operating margin", had the highest score. Thus, it can be concluded that the field of imaging is faced with the challenges of increasing service use, declining reimbursements, and staff shortages. In such an economically challenging environment, it 
becomes crucial for the MIDs to monitor their performance so that they can provide a high quality of services while staying within operational boundaries [13].

Certainly, addressing all requirements to build dashboard interface is important. Trust, usefulness, and usability are crucial issues for professional users; and it is important that the features installed work properly and meet the privacy standards. Accordingly, the literatures have been reviewed to identify the user interface requirements from different perspectives. For example, Benny evaluated dashboard tools based on user perspective. Users fall into four groups including information consumers, power users ,developers , and administrators [61]. Malik believes that a successful dashboard deployment heavily depends on the features within its supporting software and the software features may be divided into 8 major categories including end-user experience, user management, drill-down, reporting, data connectivity, visualization, collaboration, and system requirements[24].

Mohanty explains that there are different criteria for evaluation of a suitable dashboard including design, analysis, delivery, administration, scalability, availability, performance, infrastructure, and vendor [25]. Bernie presented a systematic approach to assess a brilliant dashboard from information representation perspective. He provided 54 questions to cover most areas of dashboard design including visual design, layout, structure, charts, targets, axes, trending, labeling, text and visual clarity [26]. While Gemignani suggested a checklist for evaluating dashboard alerts. He believes that the alerts are a mechanism to turn the focus to the exceptions, outliers and data highlights. Whether embedded in the dashboard or presented separately, alerts can be used as an extra layer of abstraction to make a dashboard more useful. In this checklist, four C's are considered for effective alerts. The four C's are Context, Cogency, Communication, and Control [27].

Eckerson explained that there are 10 different evaluation criteria for dashboards including rules engine, alerts and agents, time-series analysis, drill to detail, collaboration, strategy mapping, customization, and personalization [28]. Dolan et al. evaluated dashboard using measurements that were designed to assess ease of use, acceptability, and decisional conflict with an open-ended qualitative analysis. They introduced a questionnaire with 21 items which was designed to measure dashboard's ease of use and acceptability derived from two validated instruments to measure users' evaluations of computer-based tools namely the Unified Theory of Acceptance and Use of Technology (UTAUT) and the webqual instrument. The resulting scale included four component sub-scales: mechanical ease of use, cognitive ease of use, emotional difficulty, and decision-aiding effectiveness [30]. This study revealed a set of features and their relevant elements for building the dashboard that can be used for all types of dashboards. Align with progression in dashboard technology, comparative study and users' feedback will lead to further improvement in this field.

MID is a service-oriented, data-intensive and technology- driven environment and therefore, the key points which should be considered in its design are organizational culture, determining goals of dashboard design, involving users, aligning with organizational goals, determining key performance indicators and benchmark standards, data, knowledge discovery, security, flexibility, time frame, representation, dashboard evaluation, and architectural and technical considerations [7]. most important technical points that are necessary to develop an effective dashboard are to design a data warehouse for gathering data from a variety of systems such as clinical information system and financial information system in order to get comprehensive data sets, utilize interoperability standards such as HL7 messaging standards and DICOM to make connections and data exchange among different systems, and use agents in data models for registering and managing alerts if alerts are to be shown in groups or individual $[6,7,35,46]$.

Although Radiology Management Dashboard was designed specifically for the management of department with a special focus on limited indicators, this development strategy had potential to be rolled out to other KPI metrics in this department in order to drive the managers to achieve goals, improve quality of services, make decision in less time, reduce errors, and also improve the capacity and workflow management, resource allocation, cost management, and planning for expansion and growth. Finally, it can be concluded that to develop dashboard aligning with achieving high quality performance, management of information is essential. 


\section{Acknowledgements}

Thanks to Innovation Initiative of Tehran University of Medical Sciences and the Iranian Society of Radiology for help in conducting this research.

\section{APPENDICES}

-Table 17, $>$ Table 18

\section{Conflicts of Interest}

We have no conflicts of interest in the research.

\section{Protection of Human and Animal Subjects}

Human and/or animal subjects were not included in the project. 


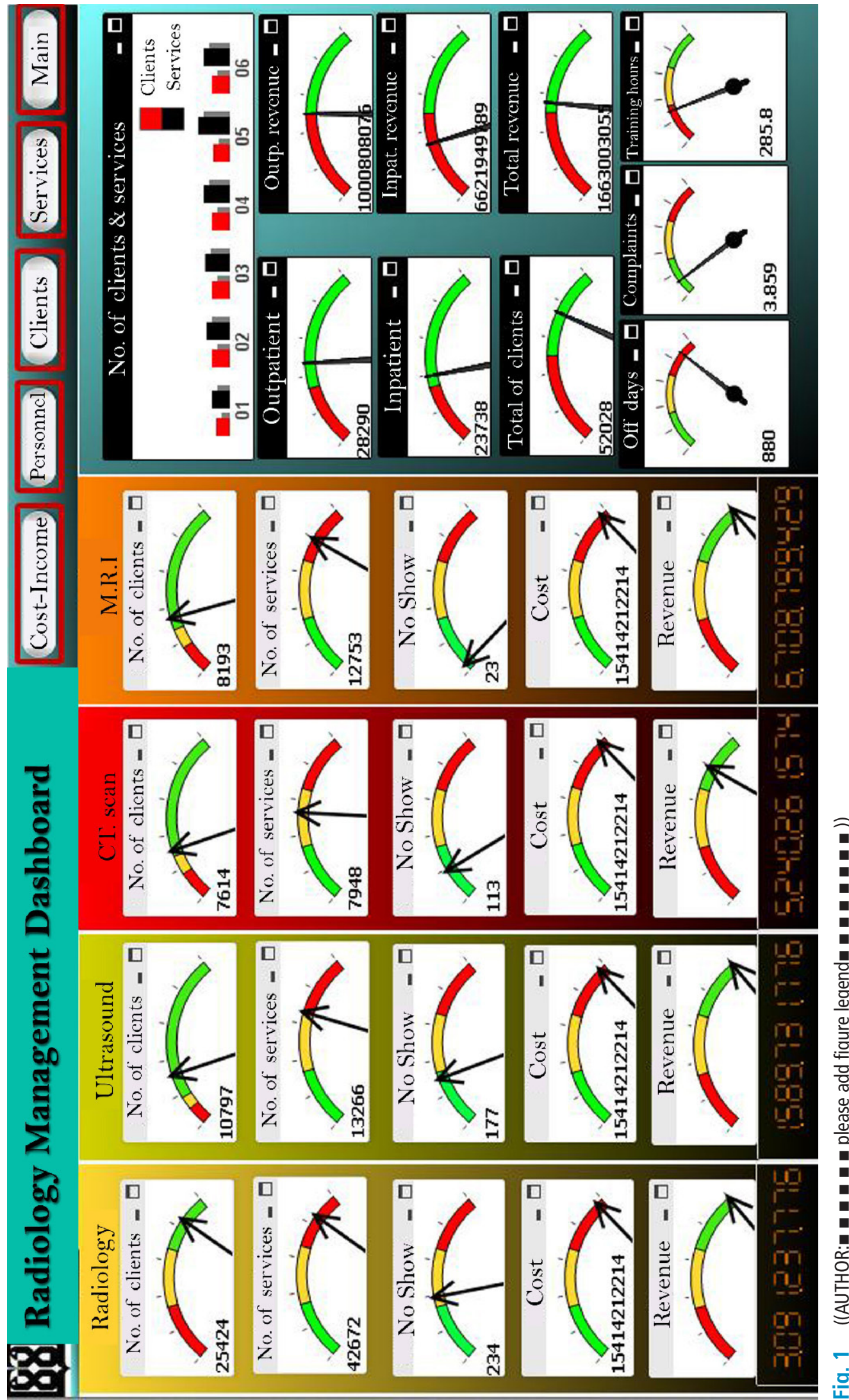

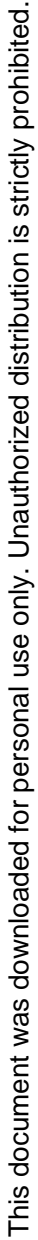


Table 1 KPI metrics related to patient safety and quality of care

\begin{tabular}{|c|c|c|c|c|}
\hline Row & Metrics & Mean & STD & CV \\
\hline 1 & Patient identification error rate & 9 & 1.68 & 0.18 \\
\hline 2 & Site identification error rate & 9 & 1.85 & 0.20 \\
\hline 3 & Side identification error rate & 9 & 1.29 & 0.14 \\
\hline 4 & Specimen labeling error rate & 9 & 1.04 & 0.11 \\
\hline 5 & Patient fall with harm rate & 8.7 & 1.83 & 0.21 \\
\hline 6 & Protocol selection error rate & 8.5 & 1.53 & 0.18 \\
\hline 7 & Procedure selection error rate & 8.3 & 1.75 & 0.21 \\
\hline 8 & Image labeling error rate & 8.3 & 1.51 & 0.18 \\
\hline 9 & Hazard related to equipment rate & 8.3 & 1.67 & 0.20 \\
\hline 10 & Post-procedure hematomas rate & 8.1 & 1.71 & 0.21 \\
\hline 11 & Improper dose rate & 8.1 & 1.54 & 0.19 \\
\hline 12 & Error rate of image interpretation & 7.9 & 2.27 & 0.28 \\
\hline 13 & Radiologic-induced pneumothorax rate & 7.8 & 1.97 & 0.25 \\
\hline 14 & Skin Impairment rate & 7.8 & 1.78 & 0.22 \\
\hline 15 & Medication allergy rate & 7.6 & 1.87 & 0.24 \\
\hline 16 & Contrast material-induced nephropathy rate & 7.5 & 1.41 & 0.18 \\
\hline 17 & Medication error rate & 7.3 & 2.21 & 0.30 \\
\hline 18 & Critical test reporting rate & 7.3 & 1.65 & 0.22 \\
\hline 19 & Adverse drug reactions rate & 7.1 & 2.53 & 0.35 \\
\hline 20 & Hazard related to environment rate & 6.9 & 2.34 & 0.33 \\
\hline 21 & Critical results reporting rate & 6.9 & 2.52 & 0.36 \\
\hline 22 & Contrast-media reactions rate & 6.7 & 1.80 & 0.26 \\
\hline 23 & Radiologic-induced infection rate & 6.7 & 1.35 & 0.20 \\
\hline 24 & Failure rate of electronic information transfer rate & 6.3 & 2.77 & 0.43 \\
\hline 25 & Order entry error rate & 6.1 & 2.35 & 0.35 \\
\hline 26 & Intravenous extravasations rate & 5.9 & 1.58 & 0.26 \\
\hline
\end{tabular}

Table 2 KPI metrics related to medical imaging services

\begin{tabular}{|c|c|c|c|c|}
\hline Row & Metrics & Mean & STD & CV \\
\hline 1 & Examination volume & 9 & 2.43 & 0.27 \\
\hline 2 & Examination volume per modality & 9 & 1.35 & 0.15 \\
\hline 3 & Repeat/reject rates & 9 & 1.65 & 0.18 \\
\hline 4 & Report turnaround time & 8.9 & 1.16 & 0.13 \\
\hline 5 & Number of examination completed but not interpreted & 8.7 & 2.64 & 0.30 \\
\hline 6 & Report accuracy rate & 8.6 & 1.78 & 0.20 \\
\hline 7 & Image turnaround time & 8.5 & 1.79 & 0.21 \\
\hline 8 & Patient wait time & 8.5 & 2.34 & 0.27 \\
\hline 9 & Report Dictated but not signed & 8 & 1.33 & 0.16 \\
\hline 10 & Radiology/pathology report correlation & 7.8 & 2.89 & 0.37 \\
\hline
\end{tabular}


Table 2 Continued

\begin{tabular}{|c|l|c|c|c|}
\hline Row & Metrics & Mean & \multicolumn{1}{|l|}{ STD } & \multicolumn{1}{|c|}{ CV } \\
\hline 11 & Radiology/ultrasound report correlation & 7.7 & 2.19 & 0.28 \\
\hline 12 & Rate of work interruptions in PACS & 7.3 & 1.16 & 0.16 \\
\hline 13 & Appointment Availability & 7.3 & 2.89 & 0.39 \\
\hline 14 & Rat of Images no sent & 7.1 & 1.55 & 0.21 \\
\hline 15 & Sample delivery times to pathology laboratory & 6.9 & 1.72 & 0.24 \\
\hline 17 & Number of examinations ordered but not performed & 6.9 & 1.78 & 0.25 \\
\hline
\end{tabular}

Table $3 \mathrm{KPI}$ metrics related to internal and external customers

\begin{tabular}{|c|l|r|r|r|}
\hline Row & Metrics & Mean & \multicolumn{1}{|c|}{ STD } & \multicolumn{1}{c|}{ CV } \\
\hline 1 & Number of Patient Complaints & 9 & 1.06 & 0.11 \\
\hline 2 & Number of Referring Physician Complaints & 7.9 & 2.18 & 0.27 \\
\hline 3 & Number of Employee Complaints & 7.3 & 3.56 & 0.48 \\
\hline 4 & $\begin{array}{l}\text { * Proportion of patients referred from the Institute (Inter- } \\
\text { nal) to patients referred from other centers (external) }\end{array}$ & 7.1 & 2.66 & 0.37 \\
\hline 5 & $\begin{array}{l}\text { * Percentage or proportion of referrals from neighboring city } \\
\text { or provinces }\end{array}$ & 6.9 & 1.38 & 0.20 \\
\hline
\end{tabular}

Table $4 \mathrm{KPI}$ metrics related to research and teaching

\begin{tabular}{|c|c|c|c|c|c|}
\hline Row & Groups & Metrics & Mean & STD & CV \\
\hline 1 & \multirow[t]{5}{*}{ Research } & Amount of funding received & 7 & 1.56 & 0.22 \\
\hline 2 & & Contribution rate of radiology department resources to research & 7 & 1.96 & 0.28 \\
\hline 3 & & Number of publications in journals & 6.9 & 1.74 & 0.25 \\
\hline 4 & & Number of presentations delivered internally and externally & 6.5 & 1.76 & 0.27 \\
\hline 5 & & Number of patents & 5.3 & 1.82 & 0.34 \\
\hline 6 & \multirow[t]{7}{*}{ Teaching } & * Ratio of number of patients to number of residents /fellowships & 8.3 & 1.34 & 0.16 \\
\hline 7 & & *Ratio of number of residents to number of faculty members & 7.8 & 0.69 & 0.08 \\
\hline 8 & & * Ratio of number of fellowships to number of faculty members & 7.8 & 1.73 & 0.22 \\
\hline 9 & & Number of courses or training sessions requested and delivered & 7.3 & 2.18 & 0.29 \\
\hline 10 & & $\begin{array}{l}{ }^{*} \text { Access rate to internet and modern literature, including books and } \\
\text { articles }\end{array}$ & 7.3 & 1.84 & 0.25 \\
\hline 11 & & Number of residents/fellows & 6.9 & 1.84 & 0.26 \\
\hline 12 & & Number of training seats available & 6.7 & 1.77 & 0.26 \\
\hline
\end{tabular}


Table 5 KPI metrics related to resource utilization

\begin{tabular}{|c|c|c|c|c|c|}
\hline Row & Groups & Metrics & Mean & STD & CV \\
\hline 1 & \multirow{5}{*}{$\begin{array}{l}\text { Radiology } \\
\text { equipment }\end{array}$} & Number of late-generation imaging devices & 8.3 & 1.64 & 0.19 \\
\hline 2 & & Percentage of time when equipment is unavailable & 7.8 & 1.78 & 0.22 \\
\hline 3 & & Ratio of number of hours available to number of hours in use & 7.6 & 1.23 & 0.16 \\
\hline 4 & & Average age (in months) of major imaging systems & 7.5 & 1.36 & 0.18 \\
\hline 5 & & $\begin{array}{l}\text { Variance in number of hours of scheduled maintenance from } \\
\text { manufacturer recommendations }\end{array}$ & 7.5 & 1.77 & 0.23 \\
\hline 6 & \multirow{7}{*}{$\begin{array}{l}\text { Radiology } \\
\text { Staff }\end{array}$} & Number of reports generated per radiologist & 8.3 & 2.87 & 0.34 \\
\hline 7 & & Number of examinations performed per technician & 7.9 & 2.19 & 0.27 \\
\hline 8 & & Ratio of number of technician to number of machines & 7.3 & 1.16 & 0.16 \\
\hline 9 & & *Number of reports generated per typist & 6.9 & 1.33 & 0.19 \\
\hline 10 & & * Ratio of number of patients to number of admissions staff & 6.7 & 1.53 & 0.22 \\
\hline 11 & & *Number of Radiologists with subspecialty qualifications & 6.7 & 2.87 & 0.42 \\
\hline 12 & & ${ }^{*}$ The number of medical physicists & 6.5 & 1.18 & 0.18 \\
\hline
\end{tabular}

Table $6 \mathrm{KPI}$ metrics related to financial performance

\begin{tabular}{|c|c|c|c|c|c|}
\hline Row & Groups & Metrics & mean & STD & CV \\
\hline 1 & \multirow[t]{2}{*}{ revenue } & Measure of total amount reimbursed & 8.7 & 1.35 & 0.15 \\
\hline 2 & & Measure of total amount billed & 8.6 & 1.76 & 0.20 \\
\hline 3 & \multirow[t]{7}{*}{ Expenses } & Measure of costs per examinations performed & 8.3 & 1.92 & 0.23 \\
\hline 4 & & Total amount of bills rejected by insurers & 8 & 2.23 & 0.27 \\
\hline 5 & & Total costs of salary and benefits & 7.9 & 2.26 & 0.28 \\
\hline 6 & & Total cost of expendable & 7.9 & 1.67 & 0.21 \\
\hline 7 & & $\begin{array}{l}\text { Total costs of equipment (purchase, installation and } \\
\text { maintenance) }\end{array}$ & 7.2 & 2.90 & 0.40 \\
\hline 8 & & $\begin{array}{l}\text { *Total amount of benefits paid to each employee as a } \\
\text { fee for service }\end{array}$ & 6.9 & 2.12 & 0.30 \\
\hline 9 & & ${ }^{*}$ Total costs of advertising & 6.1 & 1.78 & 0.29 \\
\hline 10 & \multirow{2}{*}{$\begin{array}{l}\text { Financial } \\
\text { productivity }\end{array}$} & Net operating margin & 8.9 & 2.18 & 0.24 \\
\hline 11 & & $\begin{array}{l}\text { Ratio of total labor costs (salary, benefits, and contract } \\
\text { labor) to total revenue }\end{array}$ & 7.7 & 2.12 & 0.27 \\
\hline
\end{tabular}

Table $7 \mathrm{KPI}$ metrics related to excellence in workplace

\begin{tabular}{|c|l|c|l|l|}
\hline Row & Metrics & mean & STD & CV \\
\hline 1 & Numbers of courses and training programs offered & 8 & 0.98 & 0.12 \\
\hline 2 & Number of reported incidents & 7.4 & 0.73 & 0.09 \\
\hline 3 & Total amount of pay incentives disbursed for excellent performance & 7.3 & 2.23 & 0.30 \\
\hline 4 & Percentage of staff participating in training course & 6.9 & 1.24 & 0.17 \\
\hline 5 & *Average working hours of technicians the Institute during the day & 6.7 & 2.05 & 0.30 \\
\hline 6 & *Average working hours of radiologist at the Institute during the day & 6.6 & 1.45 & 0.21 \\
\hline
\end{tabular}


Table 7 Continued

\begin{tabular}{|c|l|c|c|c|}
\hline Row & Metrics & mean & STD & CV \\
\hline 7 & Number of awards distributed & 6.3 & 2.96 & 0.47 \\
\hline 8 & Average overtime hours worked (per employee) & 5.9 & 1.67 & 0.28 \\
\hline 9 & $\begin{array}{l}\text { *Number of radiologists and/or technologists working in the regional, } \\
\text { national or international scientific or professional positions }\end{array}$ & 5.7 & 1.72 & 0.30 \\
\hline
\end{tabular}

Table 8 Selected KPI metrics for display in Radiology Management Dashboard based on available data at the study site

\begin{tabular}{|c|c|c|c|c|}
\hline Row & $\begin{array}{l}\text { Selected KPI } \\
\text { metrics for } \\
\text { display in } \\
\text { dashboard }\end{array}$ & Description & Numerator & Denominator \\
\hline \multirow[t]{2}{*}{1} & \multirow{2}{*}{$\begin{array}{l}\text { Number of ser- } \\
\text { vices }\end{array}$} & \multirow{2}{*}{$\begin{array}{l}\text { The number of ser- } \\
\text { vices provided in the } \\
\text { MID }\end{array}$} & No. of services per modality & Total no. of services \\
\hline & & & No. of services per radiologist & Total no. of services \\
\hline 2 & No show & $\begin{array}{l}\text { The number of pa- } \\
\text { tients' failure to } \\
\text { keep scheduled MID }\end{array}$ & $\begin{array}{l}\text { No. of patients' failure to } \\
\text { keep scheduled MID }\end{array}$ & $\begin{array}{l}\text { Total no. of patients who have } \\
\text { been examined }\end{array}$ \\
\hline \multirow[t]{5}{*}{3} & \multirow[t]{5}{*}{$\begin{array}{l}\text { Number of } \\
\text { clients }\end{array}$} & \multirow{5}{*}{$\begin{array}{l}\text { The number of pa- } \\
\text { tients who were re- } \\
\text { ferred to MID to re- } \\
\text { ceive imaging ser- } \\
\text { vices }\end{array}$} & $\begin{array}{l}\text { No. of inpatients per moda- } \\
\text { lity, }\end{array}$ & Total no. of clients per modality \\
\hline & & & $\begin{array}{l}\text { No. of outpatients per moda- } \\
\text { lity, }\end{array}$ & Total no. of clients per modality \\
\hline & & & $\begin{array}{l}\text { Total no. of patients per mo- } \\
\text { dality }\end{array}$ & None \\
\hline & & & No. of inpatient & Total no. of patients \\
\hline & & & No. of outpatient & Total no. of patients \\
\hline 4 & $\begin{array}{l}\text { Number of days } \\
\text { off }\end{array}$ & $\begin{array}{l}\text { The number of days } \\
\text { that staff were not } \\
\text { present in the MID }\end{array}$ & Total no. of days off & None \\
\hline \multirow[t]{6}{*}{5} & \multirow[t]{6}{*}{$\begin{array}{l}\text { Number of train- } \\
\text { ing hours }\end{array}$} & \multirow{6}{*}{$\begin{array}{l}\text { The number of hours } \\
\text { spent on training } \\
\text { courses for the stu- } \\
\text { dent in the MID }\end{array}$} & $\begin{array}{l}\text { No. of hours spent on training } \\
\text { courses for the students of } \\
\text { medicine }\end{array}$ & $\begin{array}{l}\text { Total no. of hours spent on train- } \\
\text { ing courses for the students }\end{array}$ \\
\hline & & & $\begin{array}{l}\text { No. of hours spent on training } \\
\text { courses for the residents }\end{array}$ & $\begin{array}{l}\text { Total no. of hours spent on train- } \\
\text { ing courses for the students }\end{array}$ \\
\hline & & & $\begin{array}{l}\text { No. of hours spent on training } \\
\text { courses for the fellowship }\end{array}$ & $\begin{array}{l}\text { Total no. of hours spent on train- } \\
\text { ing courses for the students }\end{array}$ \\
\hline & & & $\begin{array}{l}\text { No. of hours spent on training } \\
\text { courses for the }\end{array}$ & $\begin{array}{l}\text { Total no. of hours spent on train- } \\
\text { ing courses for the students }\end{array}$ \\
\hline & & & $\begin{array}{l}\text { No. of hours spent on training } \\
\text { courses for the students of } \\
\text { radiology technology }\end{array}$ & $\begin{array}{l}\text { Total no. of hours spent on train- } \\
\text { ing courses for the students }\end{array}$ \\
\hline & & & $\begin{array}{l}\text { No. of hours spent on training } \\
\text { courses for other higher edu- } \\
\text { cation students }\end{array}$ & $\begin{array}{l}\text { Total no. of hours spent on train- } \\
\text { ing courses for the students }\end{array}$ \\
\hline \multirow[t]{2}{*}{6} & \multirow[t]{2}{*}{$\begin{array}{l}\text { Number of com- } \\
\text { plaints }\end{array}$} & \multirow{2}{*}{$\begin{array}{l}\text { The number of pa- } \\
\text { tient complaints } \\
\text { about MID }\end{array}$} & $\begin{array}{l}\text { no. of patient complains per } \\
\text { modality }\end{array}$ & Total no. of complaints \\
\hline & & & no. of other complaints & Total no. of complaints \\
\hline
\end{tabular}


Table 8 Continued

\begin{tabular}{|c|c|c|c|c|}
\hline Row & $\begin{array}{l}\text { Selected KPI } \\
\text { metrics for } \\
\text { display in } \\
\text { dashboard }\end{array}$ & Description & Numerator & Denominator \\
\hline \multirow[t]{3}{*}{7} & \multirow[t]{3}{*}{ Revenue } & \multirow{3}{*}{$\begin{array}{l}\text { The amount of rev- } \\
\text { enue of the MID }\end{array}$} & Revenues per modality & Total no. of revenue \\
\hline & & & Inpatient revenue & Total no. of revenue \\
\hline & & & Outpatient revenue & Total no. of revenue \\
\hline \multirow[t]{4}{*}{8} & \multirow[t]{4}{*}{ Costs } & \multirow[t]{4}{*}{$\begin{array}{l}\text { The amount of costs } \\
\text { related to the MID }\end{array}$} & $\begin{array}{l}\text { The costs related to require- } \\
\text { ments }\end{array}$ & Total no. of costs \\
\hline & & & The costs related to salaries & Total no. of costs \\
\hline & & & $\begin{array}{l}\text { The costs related to purchase, } \\
\text { installation and maintenance } \\
\text { of machines }\end{array}$ & Total no. of costs \\
\hline & & & total costs per modality & Total no. of costs \\
\hline
\end{tabular}

Table 9 Feature of user customization and related elements

\begin{tabular}{|c|l|l|c|l|l|}
\hline Row & Groups & Key elements & Rank & Agree & Disagree \\
\hline 1 & Customizing & Gode & NO.(\%) & NO.(\%) \\
\hline 2 & Definitions & Metrics & 1 & $40(100 \%)$ & 0 \\
\hline 3 & & End targets & 1 & $40(100 \%)$ & 0 \\
\hline 4 & & Objectives & $40(100 \%)$ & 0 \\
\hline 5 & & calculations & $40(100 \&)$ & 0 \\
\hline 6 & & Correlation among metrics & 3 & $38(95 \%)$ & $2(2.5 \%)$ \\
\hline 7 & Categorization & $\begin{array}{l}\text { Restricted access to specific } \\
\text { metrics by different users }\end{array}$ & 1 & $37(92.5 \%)$ & $3(7.5 \%)$ \\
\hline 8 & & Assigning a group of users to a & 1 & $38(95 \%)$ & $2(5 \%)$ \\
\hline 9 & Feedback & Aroup of dashboards & & $39(97.5 \%)$ & \\
\hline 10 & & Attach comments to metrics & 1 & $37(92.5 \%)$ & $3(7.5 \%)$ \\
\hline & Discussion forum among users & 5 & $36(90 \%)$ & $4(10 \%)$ \\
\hline
\end{tabular}

Table 10 Feature of knowledge discovery and related elements

\begin{tabular}{|c|l|c|l|l|}
\hline Row & Key elements & Rank & Agree & Disagree \\
\hline 1 & Drill-down features & Mode & NO.(\%) & NO.(\%) \\
\hline 2 & Dimensional modeling with hierarchies and levels & 1 & $40(100 \%)$ & 0 \\
\hline 3 & Dependency analysis & 1 & $39(97.5 \%)$ & $2(5 \%)$ \\
\hline 4 & Move from monitoring layer to analysis layer & 1 & $40(100 \%)$ & 0 \\
\hline 5 & What-if analysis & 2 & $40(100 \%)$ & 0 \\
\hline
\end{tabular}


Table 11 Feature of security and related elements

\begin{tabular}{|c|l|c|l|l|}
\hline Row & Key elements & Rank & Agree & Disagree \\
\hline 1 & Appropriate authentication and authorization methods & 1 & $40(100 \%)$ & 0 \\
\hline 2 & Backup and restore procedures & 1 & $40(100 \%)$ & 0 \\
\hline 3 & Audit trails & 1 & $38(95 \%)$ & $2(5 \%)$ \\
\hline 4 & Protecting data from change & 1 & $40(100 \%)$ & 0 \\
\hline 5 & Defining role-based security & 1 & $39(97.5 \%)$ & $1(2.5 \%)$ \\
\hline 6 & Automatic accessibility change by change in user roles or & 1 & $38(95 \%)$ & $2(5 \%)$ \\
\hline 7 & groups & & & No. (\%) \\
\hline
\end{tabular}

Table 12 Feature of information delivery and related elements

\begin{tabular}{|c|l|l|l|l|}
\hline Row & Key elements & \multicolumn{2}{|l|}{ Rank } & \multicolumn{2}{l|}{ Agree } & Disagree \\
\hline & Mode & NO. (\%) & NO. (\%) \\
\hline 1 & Reasonable response time and latency & 1 & $40(100 \%)$ & 0 \\
\hline 2 & Scheduling automatic reports & 1 & $40(100 \%)$ & 0 \\
\hline 3 & $\begin{array}{l}\text { Exporting information to spreadsheets, } \\
\text { presentation slides, word, PDF, etc }\end{array}$ & 1 & $40(100 \%)$ & 0 \\
\hline 5 & Data filtering for selected reports & 1 & $40(100 \%)$ & 0 \\
\hline 6 & Updating the reports & 1 & $40(100 \%)$ & 0 \\
\hline 7 & Customized layout of metrics for print & 2 & $40(100 \%)$ & 0 \\
\hline 8 & Sorting the report & 3 & $40(100 \%)$ & 0 \\
\hline & Inserting/deleting columns & 6 & $40(100 \%)$ & 0 \\
\hline
\end{tabular}

Table 13 Feature of visual design and related elements

\begin{tabular}{|c|l|c|l|l|}
\hline Row & Key elements & Rank & Agree & Disagree \\
\cline { 3 - 5 } & & Mode & NO.(\%) & NO.(\%) \\
\hline 1 & Visual intelligence to highlight areas and values & 1 & $39(97.5 \%)$ & $1(2.5 \%)$ \\
\hline 2 & Inclusion of metric definition and calculation & 1 & $40(100 \%)$ & 0 \\
\hline 3 & Linking objectives with metrics & 1 & $39(97.5 \%)$ & $1(2.5 \%)$ \\
\hline 4 & Linking metrics together & 1 & $39(97.5 \%)$ & $1(2.5 \%)$ \\
\hline 5 & Having Metadata and help & 1 & $39(97.5 \%)$ & $1(2.5 \%)$ \\
\hline 6 & Table and chart on same screen & 2 & $38(95 \%)$ & $2(5 \%)$ \\
\hline 7 & Toggling between tabular and chart views & 2 & $40(100 \%)$ & 0 \\
\hline 8 & Allowing different layouts & 2 & $40(100 \%)$ & 0 \\
\hline 10 & Resizing, maximize/minimize, re-ordering of zones & 3 & $40(100 \%)$ & 0 \\
\hline & Single screen with no scrolling & 6 & $38(95 \%)$ & $2(5 \%)$ \\
\hline
\end{tabular}


Table 14 Feature of alerting and related elements

\begin{tabular}{|c|c|c|c|c|c|}
\hline \multirow[t]{2}{*}{ Row } & \multirow[t]{2}{*}{ Groups } & \multirow[t]{2}{*}{ Key elements } & Rank & Agree & Disagree \\
\hline & & & Mode & NO.(\%) & NO.(\%) \\
\hline 1 & \multirow{4}{*}{$\begin{array}{l}\text { Customizing } \\
\text { Definitions }\end{array}$} & Defining the alerts & 1 & $40(100 \%)$ & 0 \\
\hline 2 & & Placing the alerts in context & 1 & $38(95 \%)$ & $2(5 \%)$ \\
\hline 3 & & $\begin{array}{l}\text { Highlighting by color coding for } \\
\text { unexpected values }\end{array}$ & 2 & $40(100 \%)$ & 0 \\
\hline 4 & & Determining the timing of alerts & 3 & $40(100 \%)$ & 0 \\
\hline 5 & \multirow[t]{4}{*}{ Categorization } & Dashboard website & 1 & $40(100 \%)$ & 0 \\
\hline 6 & & Email & 3 & $40(100 \%)$ & 0 \\
\hline 7 & & Cell phone & 7 & $37(92.5 \%)$ & $3(7.5 \%)$ \\
\hline 8 & & pager & 8 & $38(95 \%)$ & $2(5 \%)$ \\
\hline 9 & \multicolumn{2}{|c|}{ Explaining the problem using text } & 1 & $37(92.5 \%)$ & $3(7.5 \%)$ \\
\hline 10 & \multicolumn{2}{|c|}{ Showing the next step to do } & 2 & $37(92.5 \%)$ & $3(7.5 \%)$ \\
\hline
\end{tabular}

Table 15 Feature of system connectivity \& integration and related elements

\begin{tabular}{|c|l|c|l|c|}
\hline Row & Key elements & Rank & Agree & Disagree \\
\hline 1 & $\begin{array}{l}\text { Connectivity to a variety of data sources like OLAP cubes, } \\
\text { Databases, Lists and Spreadsheets }\end{array}$ & 1 & $40(100 \%)$ & 0 \\
\hline 2 & Supporting different operating systems & 1 & $40(100 \%)$ & 0 \\
\hline 3 & Integrating with other applications & 1 & $40(100 \%)$ & 0 \\
\hline 4 & Recovering from software or hardware crash & 2 & $40(100 \%)$ & 0 \\
\hline 5 & Integrating with programmatic APIs for data \& metadata & 2 & $40(100 \%)$ & 0 \\
\hline 6 & Integrating with portals & 3 & $38(95 \%)$ & $2(5 \%)$ \\
\hline
\end{tabular}

Table 16a The list of required data (to calculate indices) that was not available in this research

\begin{tabular}{|c|c|c|c|}
\hline Row & \multicolumn{2}{|l|}{ Indicators } & Required data \\
\hline 1 & \multirow{3}{*}{\multicolumn{2}{|c|}{ Wait time }} & Arrival time \\
\hline 2 & & & Schedule time for examination \\
\hline 3 & & & Real time that examination was performed \\
\hline 4 & \multirow{4}{*}{\multicolumn{2}{|c|}{ Report related KPIs }} & Number of produced report \\
\hline 5 & & & Report recording time \\
\hline 6 & & & Report signature time \\
\hline 7 & & & Report delivery time \\
\hline 8 & \multirow[t]{5}{*}{ Reason of complaints } & \multirow[t]{5}{*}{ Complaints of patient } & Long waiting time \\
\hline 9 & & & Inappropriate treatment of staffs \\
\hline 10 & & & Long time for report delivery \\
\hline 11 & & & $\begin{array}{l}\text { Lack of staffs who are same sex with patient } \\
\text { special examination }\end{array}$ \\
\hline 12 & & & Repeat \\
\hline
\end{tabular}


Table 16a Continued

\begin{tabular}{|c|c|c|c|}
\hline Row & \multicolumn{2}{|l|}{ Indicators } & Required data \\
\hline 13 & \multirow[t]{3}{*}{ Reason of complaints } & \multirow{3}{*}{$\begin{array}{l}\text { Complaints of referring } \\
\text { physician }\end{array}$} & Bad quality image \\
\hline 14 & & & Long time for image delivery \\
\hline 15 & & & Lack of interpretation \\
\hline 16 & \multirow[t]{5}{*}{ Reason of deduction } & \multirow[t]{5}{*}{ Deductions rate } & Lack of medical imaging request \\
\hline 17 & & & Lack of imaging report \\
\hline 18 & & & Lack of imaging interpretation \\
\hline 19 & & & Lack of request date \\
\hline 20 & & & Lack of physician signature \\
\hline 21 & \multirow[t]{11}{*}{ Reason of repeat } & \multirow[t]{11}{*}{ Repeat rate } & Non-proper position \\
\hline 22 & & & Lack of experienced staff \\
\hline 23 & & & Foggy film \\
\hline 24 & & & Non-proper \\
\hline 25 & & & Non-proper labeling \\
\hline 26 & & & Non-proper processing \\
\hline 27 & & & Patient move \\
\hline 28 & & & Non-proper \\
\hline 29 & & & Non-proper radiation dose \\
\hline 30 & & & Non-cooperation \\
\hline 31 & & & Equipment failure \\
\hline 32 & \multirow[t]{8}{*}{ Equipment } & \multirow[t]{4}{*}{ Type } & Purchase time \\
\hline 33 & & & Idle time \\
\hline 34 & & & Time of Repair \\
\hline 35 & & & Time standard for daily use \\
\hline 36 & & \multirow[t]{4}{*}{ Number } & $\begin{array}{l}\text { Maintenance time base on manufacturer recom- } \\
\text { mendations }\end{array}$ \\
\hline 37 & & & Downtime \\
\hline 38 & & & The number of hours daily use \\
\hline 39 & & & The number of hours of scheduled down time \\
\hline 40 & \multirow{4}{*}{\multicolumn{2}{|c|}{ Radiation }} & Patient Height \\
\hline 41 & & & Patient Weight \\
\hline 42 & & & Medical history (illnesses and Drug Administration) \\
\hline 43 & & & Radiation history \\
\hline
\end{tabular}


Table 16b Results of SUS measurement

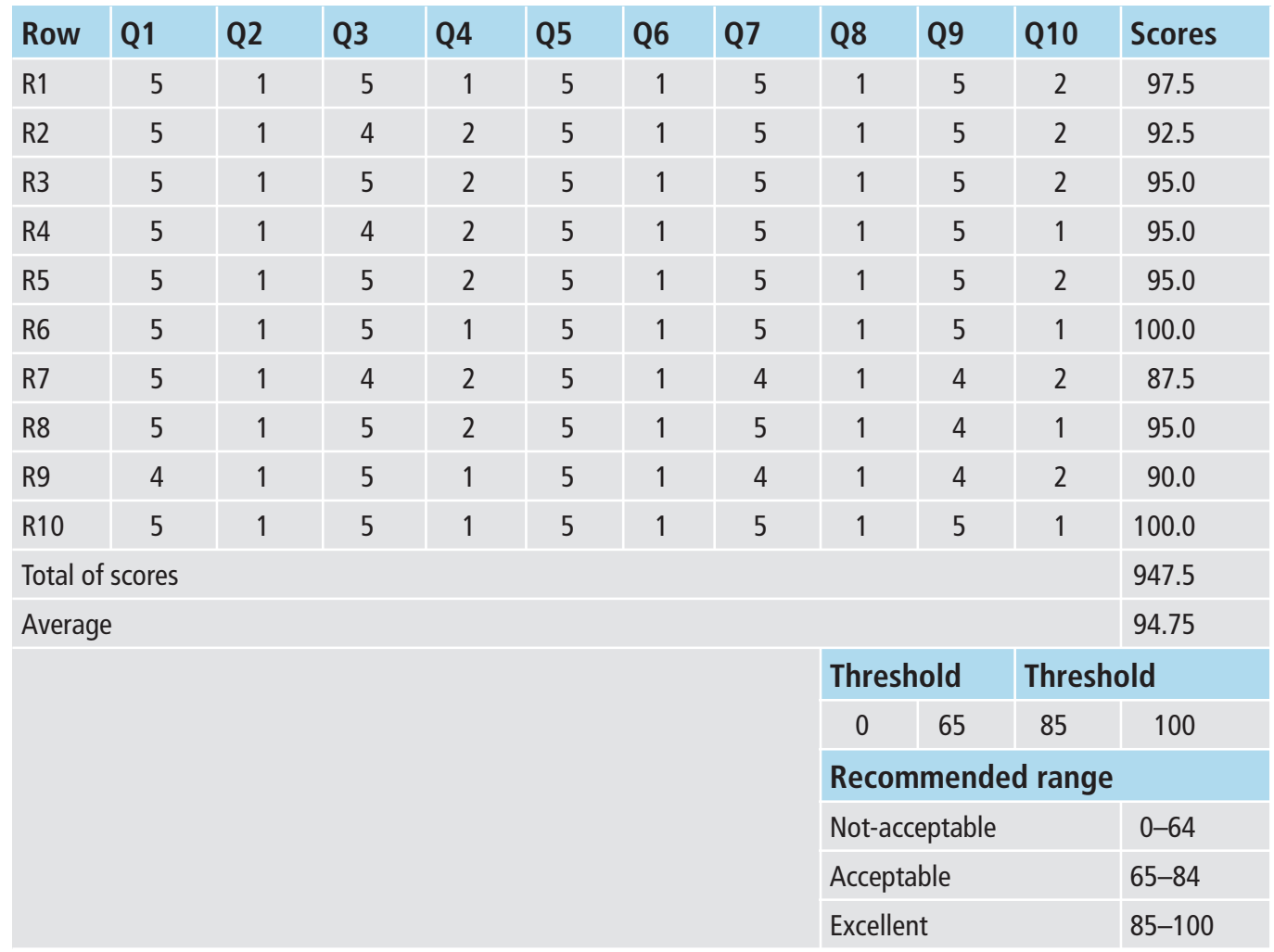

$\mathrm{R}=$ Respond

$\mathrm{Q}=$ Question

Table 17 Appendix: SUS questionnaire

\begin{tabular}{|c|c|c|c|c|c|c|}
\hline \multirow[t]{2}{*}{ Row } & \multirow[t]{2}{*}{ Questions } & \multicolumn{5}{|c|}{ Strongly disagree Strongly agree } \\
\hline & & 1 & 2 & 3 & 4 & 5 \\
\hline 1 & I think that I would like to use this system frequently. & & & & & \\
\hline 2 & I found the system unnecessarily complex. & & & & & \\
\hline 3 & I thought the system was easy to use. & & & & & \\
\hline 4 & $\begin{array}{l}\text { I think that I would need the support of a technical person } \\
\text { to be able to use this system. }\end{array}$ & & & & & \\
\hline 5 & $\begin{array}{l}\text { I found the various functions in this system were well inte- } \\
\text { grated. }\end{array}$ & & & & & \\
\hline 6 & I thought there was too much inconsistency in this system. & & & & & \\
\hline 7 & $\begin{array}{l}\text { I would imagine that most people would learn to use this } \\
\text { system very quickly. }\end{array}$ & & & & & \\
\hline 8 & I found the system very cumbersome to use. & & & & & \\
\hline 9 & I felt very confident using the system. & & & & & \\
\hline 10 & $\begin{array}{l}\text { I needed to learn a lot of things before I could get going } \\
\text { with this system. }\end{array}$ & & & & & \\
\hline
\end{tabular}


Table 18 The checklist for the evaluation of dashboard user interface (extracted from second phase of research)

\begin{tabular}{|c|c|c|c|}
\hline \multicolumn{2}{|l|}{ Key criteria } & Yes & No \\
\hline \multicolumn{4}{|l|}{ User Customization } \\
\hline \multirow[t]{6}{*}{ Customizing Definitions } & Goals & & \\
\hline & Objectives & & \\
\hline & Metrics & & \\
\hline & End targets & & \\
\hline & calculations & & \\
\hline & Correlation among metrics & & \\
\hline \multirow[t]{2}{*}{ Categorization } & $\begin{array}{l}\text { Restricted access to specific metrics by different } \\
\text { users }\end{array}$ & & \\
\hline & Assigning a group of users to a group of dashboards & & \\
\hline \multirow[t]{2}{*}{ Feedback } & Attach comments to metrics & & \\
\hline & Discussion forum among users & & \\
\hline \multicolumn{4}{|l|}{ Knowledge discovery } \\
\hline \multicolumn{4}{|l|}{ Drill-down features } \\
\hline \multicolumn{4}{|c|}{ Dimensional modeling with hierarchies and levels } \\
\hline \multicolumn{4}{|l|}{ Dependency analysis } \\
\hline \multicolumn{4}{|l|}{ What-if analysis } \\
\hline \multicolumn{4}{|c|}{ Move from monitoring layer to analysis layer } \\
\hline \multicolumn{4}{|l|}{ Security } \\
\hline \multicolumn{4}{|c|}{ Appropriate authentication and authorization methods } \\
\hline \multicolumn{4}{|l|}{ Backup and restore procedures } \\
\hline \multicolumn{4}{|l|}{ version control dashboards } \\
\hline \multicolumn{4}{|l|}{ Audit trails } \\
\hline \multicolumn{4}{|l|}{ Protecting data from change } \\
\hline \multicolumn{4}{|l|}{ Defining role-based security } \\
\hline \multicolumn{4}{|c|}{ Automatic accessibility change by change in user roles or groups } \\
\hline \multicolumn{4}{|l|}{ Information delivery } \\
\hline \multicolumn{4}{|c|}{ Reasonable response time and latency } \\
\hline \multicolumn{4}{|c|}{ Customized layout of metrics for print } \\
\hline \multicolumn{4}{|c|}{ Exporting information to spreadsheets, presentation slides, word, PDF, etc } \\
\hline \multicolumn{4}{|c|}{ Data filtering for selected reports } \\
\hline \multicolumn{4}{|l|}{ Sorting the report } \\
\hline \multicolumn{4}{|l|}{ Inserting/deleting columns } \\
\hline \multicolumn{4}{|l|}{ Scheduling automatic reports } \\
\hline Updating the reports & & & \\
\hline
\end{tabular}


Table 18 Continued

\begin{tabular}{|c|c|c|c|}
\hline \multicolumn{2}{|l|}{ Key criteria } & Yes & No \\
\hline \multicolumn{4}{|l|}{ Visual Design } \\
\hline \multicolumn{4}{|c|}{ Visual intelligence to highlight areas and values } \\
\hline \multicolumn{2}{|l|}{ Table and chart on same screen } & & \\
\hline \multicolumn{2}{|l|}{ Toggling between tabular and chart views } & & \\
\hline \multicolumn{2}{|c|}{ Resizing, maximize/minimize, re-ordering of zones } & & \\
\hline \multicolumn{2}{|l|}{ Allowing different layouts } & & \\
\hline \multicolumn{2}{|c|}{ Inclusion of metric definition and calculation } & & \\
\hline \multicolumn{2}{|l|}{ Linking objectives with metrics } & & \\
\hline \multicolumn{2}{|l|}{ Linking metrics together } & & \\
\hline \multicolumn{2}{|l|}{ Having Metadata and help } & & \\
\hline \multicolumn{2}{|l|}{ Single screen with no scrolling } & & \\
\hline \multicolumn{4}{|l|}{ Alerts } \\
\hline \multirow[t]{4}{*}{ Customizing and managing the alerts } & Defining the alerts & & \\
\hline & Highlighting by color coding for unexpected values & & \\
\hline & Determining the timing of alerts & & \\
\hline & Placing the alerts in context & & \\
\hline \multirow[t]{4}{*}{ Delivering alerts through } & Dashboard website & & \\
\hline & Email & & \\
\hline & pager & & \\
\hline & Cell phone & & \\
\hline \multicolumn{2}{|l|}{ Showing the next step to do } & & \\
\hline \multicolumn{2}{|l|}{ Explaining the problem using text } & & \\
\hline \multicolumn{4}{|l|}{ System connectivity \& integration } \\
\hline \multicolumn{2}{|c|}{ Connectivity to a variety of data sources like OLAP cubes, Databases, Lists and Spreadsheets } & & \\
\hline \multicolumn{2}{|l|}{ Supporting different operating systems } & & \\
\hline \multicolumn{2}{|l|}{ Integrating with portals } & & \\
\hline \multicolumn{2}{|l|}{ Integrating with other applications } & & \\
\hline \multicolumn{2}{|c|}{ Recovering from software or hardware crash } & & \\
\hline \multicolumn{2}{|c|}{ Integrating with programmatic APIs for data \& metadata } & & \\
\hline
\end{tabular}




\section{References}

1. Zhang J, Lu X, Nie H, Huang Z, van der Aalst WM. Radiology information system: a workflow-based approach. Int J Comput Assist Radiol Surg 2009; 4(5):509-16.

2. Karami M. Designing a Radiology Management Dashboard for Radiology Department and Implementation in Selected Hospital Affiliated to Tehran University of Medical Sciences [Phd]. Tehran: Tehran University of Medical Sciences; 2014.

3. Morgan MB, Branstetter BFt, Mates J, Chang PJ. Flying blind: using a digital dashboard to navigate a complex PACS environment. J Digit Imaging 2006; 19(1):69-75.

4. Few S. Information Dashboard Design: The Effective Visual Communication of Data first ed. Sebastopol, CA: O’Reilly Media 2006.

5. Wadsworth T, Graves B, Glass S, Harrison A, Donovan C, Proctor A. using business intelligence to improve performance. Healthcare Financial Management 2009; 63: 68-78

6. Morgan MB, Branstetter BFt, Lionetti DM, Richardson JS, Chang PJ. The radiology digital dashboard: effects on report turnaround time. J Digit Imaging 2008; 21(1): 50-8.

7. Karami M, Safdari R, Rahimi A. Effective radiology dashboards: key research findings. Radiol Manage 2013; 35(2):42-5.

8. Abujudeh HH, Kaewlai R, Asfaw BA, Thrall JH. Quality initiatives: Key performance indicators for measuring and improving radiology department performance. Radiographics 2010; 30(3): 571-80.

9. Hsu, C. and B. Sandford, The Delphi technique: making sense of consensus Practical assessment, research \& evaluation 2007;12(10): 1-8.

10. Kruskal JB, Anderson S, Yam CS, Sosna J. Strategies for establishing a comprehensive quality and performance improvement program in a radiology department. Radiographics 2009; 29(2): 315-29.

11. Ondategui Parra S. Performance indicators in academic radiology departments in the United States [Phd]. USA: Universitat Pompeu Fabra; 2008.

12. Ondategui-Parra S, Bhagwat JG, Zou KH, Gogate A, Intriere LA, Kelly P, Seltzer SE, Ros PR. Practice management performance indicators in academic radiology departments. Radiology 2004; 233(3): 716-22.

13. Ondategui-Parra S, Bhagwat JG, Zou KH, Nathanson E, Gill IE, Ros PR. Use of productivity and financial indicators for monitoring performance in academic radiology departments: U.S. nationwide survey. Radiology 2005; 236(1): 214-9.

14. Ondategui-Parra S, Erturk SM, Ros PR. Survey of the use of quality indicators in academic radiology departments. AJR Am J Roentgenol 2006; 187(5): W451-5.

15. Schultz SR, Watson RE, Jr., Prescott SL, Krecke KN, Aakre KT, Islam MN, Stanson AW.Patient safety event reporting in a large radiology department. AJR Am J Roentgenol 2011; 197(3): 684-8.

16. Steele JR, Schomer DF. Continuous quality improvement programs provide new opportunities to drive value innovation initiatives in hospital-based radiology practices. J Am Coll Radiol 2009; 6(7): 491-9.

17.Stevens A. Establishing Quality Indicators for Medical Imaging and the Basic Quality Management Toolbox. 2007 [cited 2013]; Available from: http://www.e-radimaging.com/site/article.cfm?ID=277.

18. Swensen SJ, Johnson CD. Radiologic quality and safety: mapping value into radiology. J Am Coll Radiol 2005; 2(12): 992-1000.

19. Thornton RH, Miransky J, Killen AR, Solomon SB, Brody LA. Analysis and prioritization of near-miss adverse events in a radiology department. AJR Am J Roentgenol 2011; 196(5): 1120-4.

20. Thornton E, Brook OR, Mendiratta-Lala M, Hallett DT, Kruskal JB. Application of failure mode and effect analysis in a radiology department. Radiographics 2011; 31(1): 281-93.

21. Abujudeh H, Kaewlai R, Shah B, Thrall J. Characteristics of falls in a large academic radiology department: occurrence, associated factors, outcomes, and quality improvement strategies. AJR Am J Roentgenol 2011; 197(1): 154-9.

22. Kruskal JB, Reedy A, Pascal L, Rosen MP, Boiselle PM. Quality initiatives: lean approach to improving performance and efficiency in a radiology department. Radiographics 2012; 32(2):573-87.

23. Few, S. Common Pitfalls in Dashboard Design - Perceptual Edge. 2006 [cited 2012; Available from: www. perceptualedge.com/articles/Whitepapers/Common_Pitfalls.pdf.

24. Malik S. Dashboard Evaluation: What are the Characteristics of a 'Best in Class' Enterprise Dashboard? 2007 [cited 2013]; Available from: http://www.dashboardinsight.com/articles/digital-dashboards/funda mentals/dashboard-evaluation.aspx.

25. Mohanty A. Dashboard Evaluations. 2012 [cited 2013]; Available from: http://www.slideshare.net/asismo hanty/dashboard-evaluations.

26. Bernie S. The brilliant dashboards checklist: a systemic approach to assessing your dashboard. 2012 [cited 2013]; Available from: https://madetomeasurekpis.com/tag/analysis. 
27.Gemignani Z. A dashboard alerts checklist. 2008 [cited 2013]; Available from: http://www.juiceanalytics. com/writing/dashboard-alerts-checklist. adtmag.com/articles/2005/01/01/evaluation-criteria-for-dashboards-and-scorecards.aspx.

28.Eckerson W. Evaluation criteria for dashboards and scorecards. 2005 [cited 2013]; Available from: http://adtmag.com/articles/2005/01/01/evaluation-criteria-for-dashboards-and-scorecards.aspx.

29. Eckerson W. How to Design Effective Dashboard Displays. 2011 [cited 2012]; Available from: http://www. dashboardinsight.com/articles/digital-dashboards/fundamentals/how-to-design-effective-dashboard-displays.aspx.

30.Dolan JG, Veazie PJ, Russ AJ. Development and initial evaluation of a treatment decision dashboard. BMC Med Inform Decis Mak 2013; 13:51.

31.Hughes M. Dashboard Design 101. 2010 [cited 2012]; Available from: http://www.uxmatters.com/mt/ archives/2010/11/dashboard-design-101.php.

32. Fox D. Applying Heuristic Principles to Dashboard Design \& Evaluation. 2011 [cited 2012]; Available from: http://www.claricent.com/2011/06/applying-heuristic-principles-to-dashboard-design-evaluation/.

33. Morgan MB, Chang PJ. The radiology dashboard: A user’s guide to a „high-performance“ PACS. Applied Radiology 2005; 34(5): 17-8, $20-1$.

34. Karami M, A design protocol to develop radiology dashboards. Acta Inform Med 2014; 22(5): 341-6.

35. McLellan S, Muddimer A, Camille Peres S. The Effect of Experience on System Usability Scale Ratings. Journal of usability studies 2012; 7(2): 56-67.

36. Mick J. Data-driven decision making: a nursing research and evidence-based practice dashboard. J Nurs Adm 2011; 41(10): 391-3.

37.Park KW, Smaltz D, McFadden D, Souba W. The operating room dashboard. J Surg Res 2010; 164(2): 294-300.

38. Koopman RJ, Kochendorfer KM, Moore JL, Mehr DR, Wakefield DS, Yadamsuren B, Coberly JS, Kruse RL, Wakefield BJ, Belden JL. A diabetes dashboard and physician efficiency and accuracy in accessing data needed for high-quality diabetes care. Ann Fam Med 2011; 9(5): 398-405.

39. Aydin CE, Bolton LB, Donaldson N, Brown DS, Mukerji A. Beyond Nursing Quality Measurement: The Nation's First Regional Nursing Virtual Dashboard Assessment). In: Henriksen K, Battles J, Keyes M, editors. Advances in Patient Safety: New Directions and Alternative Approaches. 2011/01/21 ed. Rockville Agency for Healthcare Research and Quality; 2008.

40. Blais R, Champagne F, Rousseau L. TOCSIN: a proposed dashboard of indicators to control healthcare-associated infections. Healthc Q 2009; 12 No Patient: 161-7.

41. McLeod B, Zaver F, Avery C, Martin DP, Wang D, Jessen K, Lang ES. Matching capacity to demand: a regional dashboard reduces ambulance avoidance and improves accessibility of receiving hospitals. Acad Emerg Med 2010; 17(12): 1383-9.

42.Zaydfudim V, Dossett LA, Starmer JM, Arbogast PG, Feurer ID, Ray WA, May AK, Pinson CW. Implementation of a real-time compliance dashboard to help reduce SICU ventilator-associated pneumonia with the ventilator bundle. Arch Surg 2009; 144(7): 656-62.

43. Waitman LR, Phillips IE, McCoy AB, Danciu I, Halpenny RM, Nelsen CL, Johnson DC, Starmer JM, Peterson JF. Adopting Real-Time Surveillance Dashboards as a Component of an Enterprisewide Medication Safety Strategy. The Joint Commission Journal on Quality and Patient Safety 2011; 37(7): 326-32.

44. Stone-Griffith S, Englebright JD, Cheung D, Korwek KM, Perlin JB. Data-driven process and operational improvement in the emergency department: the ED Dashboard and Reporting Application. J Healthc Manag 2012; 57(3): 167-80; discussion 80-1.

45. Nagy PG, Warnock MJ, Daly M, Toland C, Meenan CD, Mezrich RS. Informatics in radiology: automated Web-based graphical dashboard for radiology operational business intelligence. Radiographics 2009; 29(7): 1897-906.

46. Minnigh TR, Gallet J. Maintaining quality control using a radiological digital X-ray dashboard. J Digit Imaging 2009; 22(1): 84-8.

47. Clarke S. Your business dashboard: Knowing when to change the oil. Journal of Corporate Accounting \& Finance 2005; 16(2): 51-4.

48. Hoekzema G, Abercrombie S, Carr S, Gravel J, W Jr, Hall K. L, Kozakowski S, Mazzone M. F, Shaffer T, Wieschhaus M.Residency „dashboard“: family medicine GME’s step towards transparency and accountability? Ann Fam Med 2010; 8(5): 470.

49. Barta RA. Dashboards: a required business management tool. Biomed Instrum Technol 2010; 44(3): 228-30.

50. Johnson CD, Miranda R, Osborn HH, Miller JM, Prescott SL, Aakre KT, Denham C. Designing a safer radiology department. AJR Am J Roentgenol 2012; 198: 398-404. 
51.Balter S, Miller DL. The new Joint Commission sentinel event pertaining to prolonged fluoroscopy. J Am Coll Radiol 2007; 4: 497-500.

52. Ghiyasvan $\mathrm{H}$, Zandiyan $\mathrm{H}$, Zahirian moghadam T, Naghdi S. Cost of radiology services using the activity based costing (ABC) method. Payesh 2014; 12: 595-605.

53. Nouri F, Tabibi J, Salehi M. Outpatient flow analysis and waiting time in a radiology department. Payesh 2013; 12: 195-204.

54.Nikpazhouh A, Shariati B, Soheyli S. The costs of the radiology ward by step-down method in amir alam hospital, Tehran, Iran. Payesh 2009; 8: 235-44.

55. Swayne L, Duncan J, Ginter P. Strategic Management of Health Care Organizations. Oxford: Blackwell Publishing 2006.

56.Ez aldini ardakani F, Sheykhha M, Faghihi M. Designing an educational software for teaching and evaluation of radiology course in dentistry. Journal of medical education 2008; 12: 71-75.

57.Haghparast M, Hosseini Tashnizi M, Golverdi yazdi M, Sadeghi S, Karim T. Radiographic images repeats in Bandar Abbas teaching hospitals, Iran. Journal of Hormozgam university of medical sciences 2013; 17: $167-74$.

58. Siegelman JR, Gress DA. Radiology stewardship and quality improvement: the process and costs of implementing a CT radiation dose optimization committee in a medium-sized community hospital system. J Am Coll Radiol 2013; 10: 416-22.

59. Bhargavan M, Sunshine JH. Utilization of radiology services in the United States: levels and trends in modalities, regions, and populations. Radiology 2005; 234: 824-32.

60.Benny, A. Checklist for Evaluating Dashboarding Tools. 2010 [cited 2013; Available from: http://bennyaustin.wordpress.com/2010/03/20/checklist-for-evaluating-dashboarding-tools/. 